\title{
Kinerja Pengawas Pemilu Kab. Buton Selatan Dalam Menanggulangi Pelanggaran Pemilihan Gubernur Sulawesi Tenggara 2018
}

\author{
La Ode Marlan \\ Universitas Muhammadiyah Buton \\ Email: mardan.ode24@gmail.com
}

\begin{abstract}
Abstrak, Penelitian ini bertujuan untuk mengetahui Kinerja Panwaslu dalam Menanggulangi Pelanggaran Pemilihan Gubernur Sulawesi Tenggara 2018, dan untuk mengetahui faktor-faktor yang mempengaruhi kinerja Panwaslu. Penelitian inim engunakan metode survey yang desainya dirancang dengan menggunakan Desain Deskriptif Kualitatif. Populasi dalam penelitian ini adalaha nggota Panwaslu Kab. Buton Selatan, Sementara penarikan sampelnya menggunakan Non Probability, Sampel untuk tujuan tertentu saja yang dianggap memiliki keterkaitan dengan objek yang diteliti karena tidak semua elemen dalam populasi mendapat kesempatan yang sama untuk dapat menjadi Informan.

Hasil penelitian menunjukan, Kinerja Panwaslu Kab. Buton Selatan dalam menanggulangi Pelanggaran Pemilihan Gubernur Sulawesi Tenggara 2018, telah melaksanakan fungsinya secara baik dan maksimal, hal tersebut dapat dilihat dari pelaksaan tahapan-tahapan penyelenggaraan Pemilu, dari pengawasan pemutakhiran data pemilu (DPT), pelaksanaan kampanye, pengadaan Logistik, pelaksanaan pemungutan dan penghitungan suara, pergerakan surat suara/rekapitulasi surat suara serta pelaksanaan sosialisasi penyelenggaraan tidak ditemukan adanya Tindak Pidana pemilu, walaupun masih ada terdapat masalah-masalah lain seperti :belum maksimalnya kinerja PPS dalam melakukan pencoklitan, masihadanyawajibpilih yang belumterdaftartetapisudahmemenuhisyarat, adanya dugaan pelanggaran tindak pidana yang tidak terdeteksi, adanya pelanggaran terhadap prosedur pembukaan kotak suara, belum meratanya pemahaman stakeholder dalam melakukan pengawasan. Faktor-faktor yang mempengaruhi :(1) Kompetensi Individu, dari hasil penelitian pada Kantor Panwaslu Kab. Buton Selatan dimana Anggotanya memiliki pendidikan strata 1 (S1) dan Magister yang tentunya mempunyai Sumber Daya Manusia (SDM) yang sangat baik, dan pengalaman yang cukup menunjang serta ditopang dengan pelatihan-pelatihan yang telah dijelaskan pada bab sebelumya hal ini dapat dilihat dengan hasil yang sangat signifikan dimana tidak adanya ditemukan Pelanggaran Tindak pidana selama Pemilihan Gubernur berlangsung. (2) Dukungan Organisasi, hasil penelitian yang dilakukan oleh peneliti mengidentifikasi bahwasanya Kantor Panwaslu Kab. Buton Selatan, aspek sarana dan fasilitas kantor cukup baik, serta berbagai teknologi yang digunakan Anggota Panwaslu sangat menunjang progres dalam melakukan Pengawasan Pemlihan Gubernur. Dan Terbukanya akses serta dukungan beserta asistensi yang diberikan Stakeholder yakni KPU Kabupaten Buton Selatan, dan Bawaslu Provinsi Sulawesi Tenggara.
\end{abstract}

\section{Kata Kunci: Kinerja, Badan Pengawas Pemilu}




\section{Pendahuluan}

Reformasi politik yang dimulai pada tahun 1999 dan terus berlanjut pada masa transisi memunculkan optimisme ketika kehidupan politik memperlihatkan berbagai kemajuan substansial, seperti penyelenggaraan Pemilu 1999, 2004, 2009, dan 2014 yang terus mengalami perbaikan pada tingkatan proses dan hasil dalam rangka mengawal penyelenggaraan pemerintahan yang baik (good government) transparan, akuntabel, kredibel, dan partisipatif.

Peraturan presiden Nomor 80 Tahun 2018 Pasal 1 tentang Organisasi, tugas, Fungsi, Wewenang, dan Tata Kerja Bawaslu, Sekretariat Bawaslu Profinsi, Sekretariat Bawaslu Kabupaten/Kota dan Panwaslu Kecamatan, menjelaskan Pembentukan :

a. Badan Pengawas Pemilu, selanjutnya disingkat Bawaslu, adalah lembaga penyelenggara Pemilu yang bertugas mengawasi penyelenggaraan Pemilu diseluruh wilayah Negara Kesatuan Republik Indonesia;

b. Badan Pengawas Pemilu Provinsi, selanjutnya disingkat Bawaslu Provinsi, adalah badan yang dibentukoleh Bawaslu yang bertugas mengawasi penyelenggaraan Pemilu diwilayah provinsi;

c. Panitia Pengawas Pemilu Kabupaten/Kota, selanjutnya disingkat Panwaslu Kabupaten/Kota, adalah panitia yang dibentuk oleh Bawaslu Provinsi yang bertugas mengawasi penyelenggaraan Pemilu diwilayah kabupaten/kota;

d. Panitia Pengawas Pemilu Kecamatan, selanjutnya disingkat Panwaslu Kecamatan, adalah panitia yang dibentuk oleh Panwaslu Kabupaten/Kota yang bertugas mengawasi penyelenggaraan Pemilu diwilayah kecamatan atau nama lain;

e. Dewan Kehormatan Penyelenggara Pemilu, selanjutnya disingkat DKPP, adalah lembaga yang bertugas menangani pelanggaran kode Etik Penyelenggaraan Pemilu dan merupakan satu kesatuan fungsi.

Untuk menjamin semua rekrutmen politik itu dilaksanakan secara demokratis yang dalam Perbawaslu RI Nomor 12 Tahun 2018 Pasal 6, perubahan atas Perbawaslu Nomor 12 Tahun 2017, tentang Pengawasan Kampanye peserta Pemilihan Gubernur dan Wakil Gubernur, Bupati dan Wakil Bupati serta Walikota dan Wakil Walikota menjelaskan :

a. Bawaslu, Bawaslu Provinsi, dan/atau Bawaslu Kabupaten/Kota dibantu oleh Panwas Kecamatan dan PPL melaksanakan pengawasan Kampanye untuk 
memastikan seluruh materi dan/atau ujaran Kampanye sesuai dengan ketentuan peraturan perundang-undangan;

b. Materi dan/atau ujaran Kampanye sebagaimana dimaksud pada ayat (1) tidak memuat antara lain :

1. Mempersoalkan dasar Negara Pancasila dan Pembukaan Undang-Undang Dasar Negara Republik Indonesia Tahun 1945;

2. Menghina seseorang, agama, suku, ras, golongan, Calon Gubernur, Calon Wakil Gubernur, Calon Bupati, Calon Wakil Bupati, Calon Wali Kota, Calon Wakil Wali Kota, dan/atau Partai Politik;

3. Menghasut, memfitnah, mengadu domba Partai Politik, perseorangan, dan/atau kelompok masyarakat;

4. Mengganggu keamanan, ketentraman, dan ketertiban umum; dan/atau

5. Mengancam dan menganjurkan penggunaan kekerasan untuk mengambil alih kekuasaan dari pemerintahan yang sah.

Untuk mewujudkan penyelenggaraan pemilu demokratis, Perbawaslu RI Nomor 20 Tahun 2018 tentang Pencegahan Pelanggaran dan Sengketa Pemilihan Umum, Pasal 7 dan 8, menjelaskan sebagai berikut :

a. Pengawas Pemilu melakukan identifikasi dan pemetaan potensi pelanggaran dan sengketa proses pada :

1. Setiap tahapan Pemilu; dan

2. Aspek penting lainnya yang tidak termasuk tahapan Pemilu.

b. Identifikasi dan pemetaan sebagaimana dimaksud pada ayat (1) ditentukan berdasarkan:

1. Perintah atau larangan yang diatur dalam peraturan perundang-undangan;

2. Ketentuan peraturan perundang-undangan yang berpotensi menimbulkan multitafsir;

3. Perbuatan yang belum diatur dalam ketentuan peraturan perundangundangan;

4. Subjek atau pelaku yang berpotensi melakukan pelanggaran dan sengketa proses; dan

5. Wilayah pengawasan dengan mempertimbangan tinggi rendahnya tingkat kerawanan dan besarnya potensi pelanggaran dan sengketa proses pada wilayah tertentu berdasarkan pengalaman Pemilu sebelumnya. 
c. Berdasarkan identifikasi dan pemetaan sebagaimana dimaksud pada ayat (1) dan ayat (2), Pengawas Pemilu menentukan fokus dan strategi pengawasan. Selanjutnya Pasal 8 menjelaskan sebagai berikut :

a. Pengawas Pemilu dapat melakukan tindakan pencegahan terhadap potensi pelanggaran dan sengketa proses berdasarkan hasil identifikasi dan pemetaan.

b. Tindakan pencegahan sebagaimana dimaksud pada ayat (1) dapat dilakukan melalui:

1. penguatan koordinasi antar lembaga dalam mencegah terjadinya pelanggaran dan sengketa proses;

2. peningkatan kerja sama antar lembaga;

3. pelaksanaan sosialisasi ketentuan peraturan perundang-undangan dan/atau potensi kerawanan terjadinya pelanggaran dan sengketa proses; dan

4. kegiatan lain sepanjang tidak bertentangan dengan peraturan perundang-undangan.

Perbawaslu RI Nomor 14 Tahun 2017 tentang Penanganan Laporan Pelanggaran Pemilihan Gubernur dan Wakil Gubernur, Bupati dan Wakil Bupati, serta Walikota dan Wakil Walikota Pasal 1, menjelaskan pelanggaran pemilihan adalah sebagai berikut:

a. Pelanggaran Pemilihan adalah tindakan yang bertentangan atau tidak sesuai dengan peraturan perundang-undangan terkait Pemilihan;

b. Pelanggaran Kode Etik Penyelenggara Pemilihan adalah pelanggaran terhadap etika penyelenggara Pemilihan yang berpedomankan sumpah dan/atau janji sebelum menjalankan tugas sebagai penyelenggara Pemilihan;

c. Pelanggaran Administrasi Pemilihan adalah pelanggaran yang meliputi tata cara, prosedur, dan mekanisme yang berkaitan dengan administrasi pelaksanaan Pemilihan dalam setiap tahapan penyelenggaraan Pemilihan;

d. Tindak Pidana Pemilihan adalah tindak pidana pelanggaran dan/atau kejahatan terhadap ketentuan tindak pidana Pemilihan sebagaimana diatur dalam UndangUndang tentang Pemilihan Gubernur, Bupati,dan Wali Kota;

e. Hari adalah 1x24 (satu kali dua puluh empat) jam dalam hari. 
Perbawaslu RI Nomor 7 Tahun 2018 tentang Penanganan Temuan dan Laporan Pelanggaran pemilihan umum Pasal 9, menjelaskan kajian awal duagaan pelanggaran pemilu adalah sebagai berikut :

a. Pengawas Pemilu membuat kajian awal atas Laporan dugaan Pelanggaran Pemilu yang dituangkan dalam formulir model B.5, paling lama 2 (dua) hari sejak Laporan diterima.

b. Kajian awal Pengawas Pemilu atas Laporan Dugaan Pelanggaran Pemilu merupakan kegiatan menganalisis keterpenuhan syarat formil dan syarat materil, jenis pelanggaran, penentuan Laporan dapat registrasi atau tidak, pelimpahan Laporan sesuai dengan tempat terjadinya dugaan Pelanggaran Pemilu dan/atau Laporan Dugaan Pelanggaran Pemilu telah ditangani dan diselesaikan oleh Pengawas Pemilu sesuai dengan tingkatannya.

c. Syarat formil sebagaimana dimaksud pada ayat (2) meliputi:

1. identitas Pelapor/pihak yang berhak melaporkan;

2. pihak terlapor;

3. waktu pelaporan tidak melebihi ketentuan paling lama 7 (tujuh) hari sejak diketahui terjadinya dan/atau ditemukannya dugaan Pelanggaran Pemilu; dan

4. kesesuaian tanda tangan dalam formulir Laporan Dugaan Pelanggaran dengan kartu tanda penduduk elektronik dan/atau kartu identitas lain.

d. Syarat materil sebagaimana dimaksud pada ayat (2) meliputi :

1. peristiwa dan uraian kejadian;

2. tempat peristiwa terjadi;

3. saksi yang mengetahui peristiwa tersebut; dan

4. bukti.

e. Jenis dugaan pelanggaran sebagaimana dimaksud pada ayat (2) yaitu:

1. Pelanggaran Kode Etik Penyelenggara Pemilu;

2. Pelanggaran Administratif Pemilu;

3. Tindak Pidana Pemilu; dan/atau

4. pelanggaran peraturan perundang-undangan lainnya. 


\section{Metode Penelitian}

Jenis penelitian yang digunakan dalam penelitian ini adalah penelitian kualitatif. Dalam penelitian ini pendekatan yang dilakukan adalah melalui pendekatan kualitatif. Artinya data yang dikumpulkan bukan berupa angka-angka, melainkan data tersebut berasal dari naskah wawancara, catatan lapangan, dokumen pribadi, catatan memo, dan dokumen resmi lainnya. penelitian ini ada beberapa jenis pengumpulan yang digunakan peneliti yaitu Observasi/Pengamatan, Wawancara, dan Dokumentasi. Teknik analisis data dalam penelitian ini adalah dengan menggunakan metode deskriptif Kualitatif, Menurut Miles dan Huberman (1992) bahwa analisis deskriptif melalui tiga alur, yaitu a) Data reduction; b) Data display; c) Conclusion drawing/verification.

\section{Pembahasan}

\section{Kinerja panwaslu kab. Buton Selatan dalam Menanggulangi Pelanggaran Pemilihan Gubernur Sulawesi Tenggara 2018.}

Panwaslu Kab. Buton Selatan merupakan lembaga yang yang bersifat Ad hoc (sementara) berbeda dengan Bawaslu yang bersifat permanen. Yang dimaksud dengan ad hoc adalah Pengawas Pemilu yang dibentuk sebelum tahapan pertama pemilu (pendaftaran pemilih) dimulai dan dibubarkan setelah calon yang terpilih dalam pemilu dilantik. Pengawasan Pilkada Gubernur dan Wakil Gubernur Sulawesi Tenggara 2018,cukup baik dan dapat berjalan lancar, selama proses pengawasan berlangsung tidak ada laporan-laporan ataupun temuan yang berararti terkait tindak pidana Pilkada. Lancarnya pengawasan pilkada ini karena adanya solideritas lembaga itu sendiri, kerjasama dengan mitra/Stakeholder, sosialisasi guna menjadikan masyarakat untuk menjadi pengawas partisipatis.

Salah satu bentuk upaya pencegahan pelanggaran sebagaimana Undang-Undang Nomor 10 Tahun 2016, Panwas Kabupaten Buton Selatan menyelenggarakan program/kegiatan koordinasi dengan stakeholders pengawasan pemilu, melalui Rapat Koordinasi (Rakor) Stakeholders. Tujuan dari rakor stakeholders yaitu sebagai alat deteksi dini mencegah pelanggaran, mencegah potensi konflik dan praktik pragmatis atau politik transaksional dalam setiap Pemilu/Pemilihan. Juga diharapkan dapat mencegah secara dini Penyelenggara Pemilu yang melanggar Kode Etik Pemilu/Pemilihan. Peserta Rakor (rapat koordinasi) Stakeholder adalah para Pasangan 
Calon, tim Sukses, Partai Politik pengusung, kelompok Masyarakat, Pemda, Pers, Penyelenggara dan pengawas Pemilu/Pemilihan.

Bentuk pencegahan lain yang dilakukan oleh Panwas Kab.Buton Selatan adalah dengan melaksanakan kegiatan sosialisasi dengan masyarakat, ASN (aparatur sipil negara) dan Pemilih Pemula. Berikut Kegiatan Rakor dan Sosilaisasi Panwas Kabupaten Buton Selatan :

a. Rapat Koordinasi Pengawasan Partisipatif dengan masyarakat;

b. Sosialisasi Netralitas ASN;

c. Rapat Koordinasi dengan Stakeholder;

d. FGD Pengawasan Partisipatif;

e. Pengawasan Partisipatif Perempaun Anti Politik Uang; dan

f. Pengawasan Partisipatif Pemilih Pemula.

Panwas Kabupaten Buton Selatan juga membangun koordinasi dan kerjasama dengan berbagai pihak Kepolisisan dan Kejaksaan untuk menegakkan hukum dalam pemilihan Gubernur dan Wakil Gubernur Provinsi Sulawesi Tenggara 2018, yang kemudian direalisasikan dalam bentuk Sentra Penegakan Hukum Terpadu (GAKKUMDU).

a. Kerjasama.

Dalam meningkatkan pengawasan yang maksimal, diperlukan hubungan kelembagaan dan kerjasama dengan berbagai lembaga lain. Hal tersebut didasarkan pada keterbatasan kewenangan yang dimiliki oleh pengawas pemilu dalam melakukan pengawasan. Selain itu, membangun hubungan kelembagaan dan kerjasama dengan lembaga lain terkait kepemiluan, juga penting dalam meningkatkan kemampuan dalam pengawasan.

Sehubungan dengan hal tersebut diatas, dalam rangka mewujudkan penguatan peran dan kewenangan bawaslu RI dalam memaksimalkan tugas dipengawasan Pemilu/Pilkada yang bersih, berintegritas dan damai, bawaslu berinisiatif menjalin kerjasama dengan stakeholder diantaranya yakni dengan Media Masa, dan Lembaga yang berkaitan dengan Pengawasan Pemilihan. Tujuan dilaksanakannya hubungan antar lembaga oleh Bawaslu RI adalah sebagai berikut :

a. Melakukan koordinasi hubungan kelembagaan dan kerjasama stakeholders terkait dalam rangka memaksimalkan pengawasan pemilu/Pemilihan kepala Daerah; 
b. Mensinergikan kewenangan yang dimiliki masing-masing lembaga terkait pengawasan Pemilu/Pemilihan;

c. Tukar menukar informasi dengan stakeholder terkait tentang regulasi pengawasan Pemilu/Pilkada dalam rangkah pencegahan;

d. Melakukan penyamaan presepsi terkait fungsi dan peran masing-masing lembaga dalam pengawasan Pemilu/Pilkada yang aman, damai, dan berkualitas dalam mengawal terpilihnya pemimpin berintegritas;

Dalam melaksanakan tugas dan kewenangan tersebut, Bawaslu melibatkan pemangku kepentingan (stakeholders) dan masyarakat berpartisipasi mengawasi pemilihan tersebut guna terwujudnya efektifitas pengawasan serta terwujudnya pemilihan yang bersih, berkualitas dan bermartabat, serta melahirkan pemimpin yang amanah dan bersih.

Lembaga pengawas pemilu dibentuk untuk mengawasi pelaksanaan tahapan pemilu, menerima pengaduan, serta menangani kasus-kasus. pelanggaran administrasi dan pelanggaran pidana pemilu. lembaga yang di bentuk oleh pemerintah ketika akan di adakan pemilihan umum baik itu pemilihan Kepala Daerah (Gubernur dan Wakil Gubernur, Bupati dan Walikota), Anggota DPD, DPRD, DPR dan Pemilihan Presiden dan wakil Presiden.

Dalam pelaksanaan tugas Panwaslu Kab. Buton Selatan berpedoman pada Tugas dan Fungsi Pengawasan Pemilu yang dikeluarkan oleh Bawaslu RI. Secara umum seluruh rangkaian Pengawasan Pemilihan Umum Gubernur dan Wakil Gubernur Sulawesi Tenggara 2018 dapat berjalan lancar, masalah- masalah yang timbul sebagai perkembangan dinamika dalam setiap pemyelenggaraan pemilu dapat di selesaikan dengan memaksimalkan kordinasi dengan pihak- pihak terkait dengan penanganan pelanggaran yaitu Kepolisian dan Kejaksaan dalam wadah sentra GAKUMDU (Penegakan Hukum Terpadu).

Kajian tindak pidana gakkumdu yang diadakan setiap bulanya dan menjadi pusat aktivitas penegakan tindak pidana pemilu yang terdiri dari unsur Bawaslu, Bawaslu prov, dan/atau Bawaslu Kabupaten/KotaKepolisian RI, Kepolisian Daerah, dan/atau Kepolisian Resor, Kejaksaan Agung RI, Kejaksaan Tinggi dan/atau Kejaksaan Negeri untuk memaksimalkan penanganan pelanggaran-pelanggaran. Berdasarkan hasil penelitian yang dilakukan oleh penulis pada Kantor Panwaslu Kab. Buton Selatan, 2018 dalam melakukan pengawasan yakni semua tahapan perlu diawasi, mulai dari proses 
penetapan DPT sampai dengan pengawasan tahapan pemungutan, penghitungan dan rekapitulasi hasil perolehan suara.

Adapun kegiatan-Kegiatan yang diawasi selama proses pengawasan berlangsung adalah sebagai berikut :

\section{a. Tahapan Pemutakhiran Data dan Daftar Pemilih.}

Pengawasan terhadap Pemutakhiran Data dan Daftar Pemilih berpedoman pada Peraturan Badan Pengawas Pemilu Republik Indonesia nomor 9 Tahun 2017 Tentang Pengawasan Pemutakhiran Data Dan Daftar Pemilih Dalam Pemilihan Gubernur Dan Wakil Gubernur, Bupati Dan Wakil Bupati Serta Walikota Dan Wakil Walikota serta pelaksanaan teknisnya berdasarkan pada Peraturan KPU Nomor 2 tahun 2017 tentang Pemutakhiran Data dan Penyusunan Daftar Pemilih dalam Pemilihan Gubernur dan Wakil Gubernur, Bupati dan Wakil Bupati dan/atau Walikota dan Wakil Walikota.

Selama proses pemutakhiran data dan daftar pemilih Panitia Pengawas Pemilihan Umum Kabupaten Buton Selatan telah berkoordinasi dengan KPU Kabupaten Buton Selatan agar mengingatkan kepada PPDP dan PPS sebelum masa akhir pemutakhiran daftar pemilih agar melakukan pencermatan tehadap: (1) Pemilih pemula yang sudah berumur 17 tahun pada tanggal 27 Juni 2018 yang belum terdaftar, (2) mencoret pemilih yang sudah meninggal dunia dari daftar pemilih, (3) mencoret pemilih yang telah pindah domisili, (4) mengeluarkan pemilih yang telah berubah status dari masyarakat sipil menjadi anggota TNI/Polri atau sebaliknya dari TNI/Polri menjadi masyarakat sipil, (5) menginventarisir penduduk yang telah memenuhi syarat untuk memilih namun belum terdaftar dalam daftar pemilih, (6) pemilih Fiktif/ganda, (7) pemilih yang dicabut hak pilihnya oleh peraturan perundang-undangan, (8) pemilih yang hilang ingatan, dan (9) pemilih yang berumur 16 tahun tetapi sudah menikah.

Berdasarkan hasi pengawasan yang dilakukan oleh Panwaslu Buton Selatan diperoleh bahwa Jumlah DPT yang ditetapkan oleh KPU Buton Selatan dalam Pemilihan Gubernur dan Wakil Gubernur Provinsi Sulawesi Tenggara adalah 7 Kecamatan, 70 Desa, 161 TPS, Wajib Pilih Laki-laki sejumlah 27.417 dan Wajib Pilih Perempuan sejumlah 27.996 sehingga total DPT yang ditetapkan oleh KPU Buton Selatan adalah 55.413 Wajib Pilih dandituangkan dalam tabel berikut : 
Tabel.1

Rekapitulasi Penctipyan DPT.

DPT KABUPATEN BUTON SELATAN DALAM PEMIUHAN

GUBERNUR DAN WAKIL GUBERNUR SULAWESI TENGGARA TAHUN 2018

\begin{tabular}{|c|c|c|c|c|c|c|}
\hline \multirow[b]{2}{*}{ NO } & \multirow[b]{2}{*}{ KECAMATAN } & \multirow{2}{*}{$\begin{array}{c}\text { JUMLAH } \\
\text { DESA / } \\
\text { KELURAHA }\end{array}$} & \multirow{2}{*}{$\begin{array}{l}\text { JUMLAH } \\
\text { TPS }\end{array}$} & \multicolumn{3}{|c|}{ JUMLAH PEMILIH } \\
\hline & & & & L & $\mathbf{P}$ & $\mathbf{L}+\mathbf{P}$ \\
\hline 1 & BATAUGA & 12 & 29 & 5.020 & 5.182 & 10.202 \\
\hline 2 & BATUATAS & 7 & 16 & 3.180 & 3.163 & 6.343 \\
\hline 3 & KADATUA & 10 & 15 & 2.843 & 3.137 & 5.980 \\
\hline 4 & LAPANDEWA & 7 & 20 & 3.019 & 2.922 & 5.941 \\
\hline 5 & SAMPOLAWA & 16 & 43 & 7.082 & 7.144 & 14.226 \\
\hline$G$ & SIOMPU & 10 & 19 & 3.279 & 3.299 & 6.578 \\
\hline 7 & SIOMPU BARAT & 8 & 19 & 2.994 & 3.149 & 6.143 \\
\hline & IUMI АH & 70 & 161 & 27.417 & 27.996 & 55413 \\
\hline
\end{tabular}

Sumber :Dato Olohan Kontorfunwosiv Kah. Buton Seiatan, 201\%.

Selain itu, beberapa sub tahapan Pemutakhiran data dan daftar pemilih pada Pemilihan Gubernur dan Wakil Gubernur Sulawesi Tenggara Tahun 2018, tidak ditemukan adanya tindak pidana dan dapat diakui bahwa kelemahan dalam pengawasan terhadap tahapan Pemutakhiran data dan daftar pemilih serta pada tahapan lainnya adalah kurangnya jumlah personil dalam pengawasan yang tidak sebanding dengan luasnya wilayah yang diawasi.

Selanjutnya Proses tahapan pemutakhiran data dan daftar pemilih dalam Pemilihan Gubernur dan Wakil Gubernur Sulawesi Tenggara Tahun 2018, masalah yang muncul yaitu :

a. Pada saat sub tahapan Pencocokan dan Penelitian ditemukan ada beberapa Desa yang belum melakukan proses coklit sehingga Panitia Pengawas Pemilihan Gubernur dan Wakil Gubernur Sulawesi Tenggara Tahun 2018melalui Panwascam dan PPL melakukan himbauan lisan kepada PPS untuk segera menugaskan PPDP untuk melakukan pencoklitan;

b. Selama Proses Pemutakhiran data dan daftar pemilih masih banyak ditemukan permasalahan seperti adanya wajib pilih yang belum terdaftar tetapi sudah memenuhi syarat untuk menjadi pemilih disebabkan oleh identitas kependudukan yang tidak lengkap, masih ditemukan wajib pilih ganda, masih ditemukan dalam daftar pemilih penduduk yang sudah pindah domisili, masih 
ditemukan dalam daftar pemilih wajib pilih yang telah meninggal dunia serta berbagai indikator lainnya yang sudah dijelaskan pada bagian awal laporan ini;

c. KPU Buton Selatan dalam melakukan Pemutakhiran data dan daftar pemilih menggunakan Aplikasi SIDALIH sehingga ketika ada permasalahan dalam Daftar Pemilih tidak bisa dilakukan penyelesaian dengan cepat karena Aplikasi SIDALIH bersifat Nasional dan berbasis IT;

d. Secara garis besar dalam proses pemutakhiran data dan daftar pemilih tidak ditemukan adanya masalah yang signifikan yang dapat menghambat jalannya proses tahapan;

e. Tidak ada regulasi spesifik untuk dapat mengawasi sistem kerja SIDALIH.

Berdasarkan laporan akhir Divisi pengawasan dan hubungan antar lembaga, Seluruh tahapan Pemutakhiran data dan daftar pemilih dalam Pemilihan Gubernur dan Wakil Gubernur Provinsi Sulawesi Tenggara Tahun 2018 adalah dapat diawasi oleh Panitia Pengawas Pemilihan Umum Kabupaten Buton Selatan dengan pemberdayaan aparatur kelembagaan Panitia Pengawas Pemilihan Umum Kabupaten Buton Selatan yakni optimalisasi pengawasan yang dilakukan oleh Panwascam dan PPL selama proses Pengawasan terhadap Tahapan Pemutakhiran data dan daftar pemilih.

Tahapan Kampanye diatur dalam Peraturan KPU Nomor 4 Tahun 2017 tentang Kampanye Pemilihan Gubernur dan Wakil Gubernur, Bupati dan Wakil Bupati, dan/atau Walikota dan Wakil Walikota, Perbawaslu RI Nomor 12 Tahun 2018, perubahan atas Perbawaslu Nomor 12 Tahun 2017, tentang pengawasan Kampanye peserta Pemilihan Gubernur dan Wakil Gubernur, Bupati dan Wakil Bupati serta Walikota dan Wakil Walikota. Yang menjadi kerawanan dalam tahapan kampanye adalah sebagai berikut :

1. Kampanye diluar jadwal;

2. Keterlibatan ASN dalam kampanye;

3. Pelibatan anak dibawah umur;

4. Penggunaan fasilitas negara dan sarana ibadah;

5. Kampanye diuar zona yang ditentukan oleh KPU;

6. KPU tidak berlaku adil dan setara pada papan/laman KPU, kampanye hitam oleh pasangan calon;

Kerawanan pada massa tenang dan pembersihan Alat Peraga Kampanye adalah kampanye dimasa tenang, masih terpasang alat peraga kampanye, dan money 
politik.Sebagai kegiatan Pencegahan dalam kegiatan kampanye yang dilakukan oleh Panwas Pemilihan Buton Selatan adalah sebagai berikut :

a. Panwaslu Buton Selatan menggelar kegiatan sosialisasi Pilkada tanpa money politik dan politisasi SARA (Suku, Agama, Ras);

b. Panwaslu Buton Selatan menggelar rapat koordinasi dengan stakeholder terkait perihal penertiban Alat peraga sosialisasi berupa baliho dan spanduk dalam rangka menghadapi kampanye pasangan calon Gubernur dan Wakil Gubernur Provinsi Sulawesi Tenggara Tahun 2018;

c. Panwaslu Buton Selatan mengadakan kegiatan Bimbingan teknis kepada Panwascam dan PPL dalam rangka menghadapi Pengawasan Tahapan Kampanye Pemilihan Gubernur dan Wakil Gubernur Provinsi Sulawesi Tenggara Tahun 2018.

Selama Proses pelaksanaan kampanye berlangsung hasil-hasil dari pengawasan pada tahapan kampanye telah dimuat dalam alat kerja A2.K-4 yang dikirimkan secara periodik kepada Bawaslu Provinsi Sulawesi Tenggara yang menyatakan Tidak adanya temuan pelanggaran dalam tahapan kampanye Pemilihan Gubernur dan Wakil Gubernur Provinsi Sulawesi Tenggara 2018 oleh Panwas Kabupaten Buton Selatan.

Dalam temuan lainnya, tidak ada rekomendasi yang dikeluarkan oleh Panwaslu Buton Selatan selama masa kampanye Pemilihan Gubernur dan Wakil Gubernur Provinsi Sulawesi Tenggara Tahun 2018 yang disebabkan oleh ritme kampanye yang sangat minim oleh Pasangan Calon Gubernur dan Wakil Gubernur di Wilayah Kabupaten Buton Selatan. Ketua sekaligus Koordinator Divisi pengawasan dan hubungan antar lembaga Jumadi,S.Pd mengatakan Dalam pelaksanaan tahapan kampanye Pemilihan Gubernur dan Wakil Gubernur Sulawesi Tenggara Tahun 2018, yang menjadi dinamika danpermasalahan adalah :

a. Rentang Wilayah Pengawasan di Kabupaten Buton Selatan yang terdiri atas Kepulauan dengan fasilitas Listrik dan jaringan telekomunikasi terbatas sehingga menghambat dalam proses pelaporan adanya dugaan pelanggaran;

b. Adanya Dugaan tindakan money politik yang tidak dapat terdeteksi oleh Pengawas Pemilihan dari berbagai tingkatan.

Dengan SDM yang ada pada Panitia Pengawas Pemilihan Umum Kabupaten Buton Selatan berupaya secara optimal dalam melakukan pengawasan dalam berbagai tahapan 
yang diantaranya saling beririsan, sehingga sangat tidak menutup kemungkinan ada bagian sub-sub tahapan yang luput dari pengawasan Pengawas Pemilihan.

Dalam persiapan Pengawasan terhadap pendistribusian perlengkapan pemungutan dan penghitungan suara adalah :

a. Mengingatkan KPU agar waktu pendistribusian perlengkapan pemungutan dan penghitungan suara sesuai dengan waktu yang ditentukan;

b. Melakukan koordinasi dengan KPU terkait waktu pendistribusian perlengkapan pemungutan dan penghitungan suara;

c. Melakukan pengawasan melekat pada saat pensortiran surat suara dan pengepakan surat suara kedalam kotak suara beserta perlengkapan pemungutan dan penghitungan suara kedalam kotak suara.

Aktifitas pengawasan yang dilakukan oleh Panwaslu Kab. Buton Selatan adalah sebagai berikut :

a. Melakukan pengawasan distribusi perlengkapan pemungutan dan penghitungan suara dari KPU Provinsi ke KPU Kabupaten Buton Selatan;

b. Pengawasan melekat dalam pensortiran Surat Suara dan Perlengkapan pemungutan dan penghitungan suara lainnya;

c. Pengawasan terhadap pendistribusian C6-KWK;

d. Pada saat pendistribusian logistik dukungan pemungutan dan penghitungan surat suara tidak luput dari pengawasan oleh Panitia Pengawas Pemilihan Umum Kabupaten Buton Selatan dengan keterlibatan aktif Pengawas Pemilihan tingkat bawah yakni Panwascam, PPL dan PTPS;

e. Pengawasan melekat terhadap perpindahan kotak suara dari KPU ke PPK, dari PPK ke PPS dan dari PPS ke KPPS demikian sebaliknya dari KPPS ke PPS, PPS ke PPK dan PPK ke KPU Kabupaten Buton Selatan.

Berdasarkan laporan akhir Divisi pengawasan dan hubungan antar lembaga Pada Tahapan Logistik ada beberapa hal yang tidak dapat diawasi oleh Panitia Pengawas Pemilihan Umum Kabupaten Buton Selatan, yaitu pada proses lelang Pengadaan Logistik Kampanye Pemilihan dan Wakil Bupati Kabupaten Buton Selatan karena proses lelang dilakukan oleh ULP pada Sekretariat KPU Provinsi Sulawesi Tenggara dan dapat diakui bahwa Proses lelang (LPSE maupun dengan cara konvensional) dan korporasi pemenang sering luput dari pengawasan lembaga pengawas pemilu. 
Keberhasilan Panitia Pengawas Pemilihan Umum Buton Selatan dalam melakukan tracking terhadap bagian yang mungkin agak sulit untuk dilakukan proses tracking dan pengawasan melekat (waskat) sebagai metode yang dilakukan dalam pengawasan tahapan Logistik adalah dengan membangun komunikasi yang baik antara sesama Penyelenggara Pemilihan yakni antara KPU Kabupaten Buton Selatan dan Panitia Pengawas Pemilihan Umum dalam Pemilihan Gubernur dan Wakil Gubernur Sulawesi Tenggara Tahun 2018.

Menurut, Ketua Panwaslu sekaligus Koordinator Divisi Pengawasan dan Hubungan antar Lembaga Jumadi, S.Pd Menyatakan Dinamika dalam Produksi perlengkapan penyelenggara Pemilihan Gubernur dan Wakil Gubernur Sulawesi Tenggara Tahun 2018.

a. Proses produksi oleh rekanan, yang lelang, langsung maupun penunjukan minim pengawasan dan pengamanan;

b. Kurang cermatnya petugas validasi yang melakukan verifikasi terhadap master perlengkapan pemilihan yang akan dicetak, sehingga masih ditemui kesalahan pasca barang cetak;

c. Jadwal produksi yang tdak tepat waktu berdampak terganggunya proses berikutnya;

d. Faktor wilayah, dijumpainya kondisi yang berbeda antar titik distribusi menyangkut tentang jarak tempuh, kondisi geografis, kontur wilayah dan akses jalan serta kesesuaian moda trans;

e. Keamanan : Jaminan pengamanan percetakan perlengkapan pemilhan terutama surat suara, sejak proses pencetakan oleh rekanan, pengamanan film/sparasi surat suara.

Berdasarkat data laporan akhir Divisi pengawasan dan Hubungan Antar Lembaga menerangkan dalam pelaksanaan pengawasan Tahapan Logistik ada sub-sub bagian yang memang tidak dapat diawasi atau terhadap prosesnya sehingga tracking dan pengawasan melekat terhadap salah satu sub tahapan logistik menjadi sesuatu yang luput oleh pengawasan Panwaslu Buton Selatan disisi lain hal tersebut adalah hak yang diemban oleh Bawaslu Provinsi Sulawesi Tenggara. Perubahan Regulasi yang tidak di sertai dengan perubahan strategi dalam melakukan pengawasan adalah menjadi penghambat dalam menyesuaikanmetode pengawasan terhadap tahapan yang sedang 
berlangsung. Persiapan pengawasan dalam pemungutan dan perhitungan suara sebagai berikut :

a. Panitia Pengawas Pemilihan Umum Kabupaten Buton Selatan dalam dalam melakukan pencegahan terhadap tahapan pemungutan, penghitungan dan rekapitulasi suara adalah mendeteksi sedini mungkin adanya TPS Rawan pada saat pelaksanaan pungut hitung dalam Pemilihan Gubernur dan Wakil Gubernur Sulawesi Tenggara Tahun 2018;

b. Mempersiapkan personil Panitia Pengawas Pemilihan Gubernur dan Wakil Gubernur Sulawesi Tenggara Tahun 2018 secara vertikal dari Panwas Kabupaten, Panwascam, PPL dan PTPS;

c. Mengadakan Bimbingan Teknis Pungut Hitung kepada PTPS agar PTPS memiliki kapasitas dalam melakukan pengawasan pada saat pemungutan dan penghitungan suara pada tanggal 27 Juni 2018.

Adapun hasil dari tahapan persiapan Pengawasan, perencanaan Pengawasan, hingga kegiatan Pengawasan Mengidentifikasi :

a. Hasil dari Pemilihan berdasarkan hasil pengawasan Panwas Kabupaten Buton Selatan, diketahui Hasil Perolehan Suara Sah Pasangan Calon Gubernur dan Wakil Gubernur Sulawesi Tenggara Tahun 2018 adalah sebagai berikut :

1. H. Ali Mazi, SH - DR. Lukman Abunawas, SH., M.Si = 21.915 atau 60, 52\%;

2. DR. Ir. ASRUN, M.Eng.Sc - Ir. HUGUA = 5.982 atau 16,52\%;

3. RUSDA MAHMUD - Ir.H.L.M. SJAFEI KAHAR = 8.312 atau 22,96 \%;

4. Suara sah seluruh Pasangan Calon Bupati dan Wakil Bupati Kabupaten Buton Selatan adalah 36.209 suara;

5. Partisipatif pemilih sejumlah $65,55 \%$.

b. Hasil Rekapitulasi Data penggunaan hak pilih dan penggunaan surat suara dan hasil penghitungan suara di Tingkat Kabupaten Buton Selatan di tuangkan dalam Formulir A2.PS-5 terlampir dalam laporan.

Dalam Tahapan Pemungutan, Penghitungan, dan Rekapitulasi Hasil Perolehan Suara tidak ada Tindak Pidana yang terjadi namun ada ditemukan adanya pelanggaran terhadap prosedur pembukaan kotak suara yang menyebabkan lahirnya rekomendasi Pemungutan Suara Ulang (PSU) yang terjadi pada 7 (tujuh) TPS di dua Kecamatan di Kabupaten Buton Selatan diantaranya : (1) Kecamatan Batauga pada TPS 4 Kelurahan 
Laompo, (2) Kecamatan Siompu Barat pada TPS 1 Desa Molona, TPS 1, TPS 2, dan (3) TPS 3 Desa Watuampara TPS 1 dan TPS 2 Desa Mbanua.

Atas temuan pelanggaran tersebut, Panwascam Batauga dan Panwascam Siompu Barat merekomendasikan PSU kepada PPK Kecamatan Batauga dan PPK Kecamatan Siompu Barat. Terhadap Rekomendasi yang dikeluarkan oleh Panwacam Batauga, maka KPU segera menindak lanjuti Rekomendasi PSU dan menggelar Rapat bersama antara KPU Kabupaten Buton Selatan, Panwaslu Buton Selatan, Kepolisian Resort Buton, PPK Batauga dan PPK Siompu Barat yang termuat dalam Berita Acara Nomor : 31/PY.039.1.KPT/7415/KPU-KAB/VI/2017 (BA terlampir dalam laporan ini). Jadwal PSU dilaksanakan pada 1 Juli 2018. Sejumlah dinamika dan permasalahan terdapat dalam tahapan pemungutan, penghitungan dan rekapitulasi hasil perolehan suara adalah bersifat teknis dan administrasi yang menyebabkan terjadinya PSU (Pemungutan Suara Ulang) pada 7 (tujuh), dua Kecamatan diKabupaten Buton Selatan.

Pengawasan tahapan Pemungutan, penghitungan dan rekapitulasi hasil suara dalam Pemilihan Gubernur dan Wakil Gubernur Sulawesi Tenggara Tahun 2018 menjadi salah satu bagian dari elemen pengawasan yang dilakukan oleh Panitia Pengawas Pemilihan Umum Kabupaten Buton Selatan menjadi tanggung jawab sebagai pengawas Pemilihan dalam rangka mengsukseskan Pemilihan Gubernur dan Wakil Gubernur Sulawesi Tenggara Tahun 2018 sebagai bagian dari Pilkada Serentak Nasional Tahun 2017.

Panwaslu merupakan lembaga Negara yang idealnya melakukan kewenangannya sebagai Pengawas Pemilu dalam setiap penyelenggaraan Pemilu. Faktor-factor yang memepengaruhi kinerja panwaslu Kab. Buton Selatan sebagai berikut :

a. Kompetensi Individu, dari hasil penelitian pada Kantor Panwaslu Kab. Buton Selatan dimana Anggotanya memmiliki pendidikan strata 1 (S1) dan magister yang tentunya mempunyai Sumber Daya Manusia (SDM) yang sangat baik, dan pengalaman yang cukup menunjang serta ditopang dengan pelatihan-pelatihan yang telah dijelaskan pada bab sebelumya hal ini dapat dilihat dengan hasil yang sangat signifikandimana tidak adanya ditemukan Pelanggaran Tindak pidana selama Pemilihan Gubernur berlangsung;

b. Dukungan Organisasi, hasil penelitian yang dilakukan oleh peneliti mengidentifikasi bahwasanya Kantor Panwaslu Kab. Buton Selatan,aspek sarana dan fasilitas kantor cukup baik, serta berbagai teknologi yang digunakan Anggota 
Panwaslu sangat menunjang progres dalam melakukan Pengawasan Pemlihan Gubernur. Dan Terbukanya akses serta dukungan beserta asistensi yang diberikan Stakeholder yakni KPU Kabupaten Buton Selatan, danBawaslu Provinsi Sulawesi Tenggara.

\section{Kesimpulan}

Berdasarkan uraian yang telah dikemukakan pada bab-bab sebelumnya, maka dapatditarik kesimpulan, Peran Panwaslu Kab. Buton Selatan dalam menanggulangi pelanggaran Pemilihan Gubernur dan Wakil Gubernur Sulawesi Tenggara 2018, sudah baik dalam memaksimalkan fungsi pengawasan, walaupun masih ada terdapat permasalahan-permasalahan lain yang ditemukan.

\section{Daftar Pustaka}

Abdullah, R. (2009). Mewujudkan Pemilu Yang lebih berkualitas (Pemilu Legislatif) .

Bernardin, Jhon, and Russel, E. A. Joyce.(1998). Human Resource Management. AnExperiental Aproach.

Darmawan. B. (2005). Persepsi Penyuluhan Pertanian Terhadap Penilaian Kinerja.Bogor : MMA IPB.

Dwidjowijoto, Riant Nugroho. (2004). Kebijakan publik : Formulasi Implementasi, dan Efaluasi, Jakarta : PT. ELEX Media Komputindo.

Dedi Mulyadi, (2012), Kebijakan Legislasi tentang Sanksi Pidana Pemilu Legislatif Di Indonesia dalam Perspektif Indonesia, Jakarta, Gramata Publishing. . (2012), Kebijakan Legislasi tentang Sanksi Pidana Pemilu Legislatif di Indonesia dalam Perspektif Indonesia, Jakarta, Gramata Publishing.

H, M. R. (2006). Human Resource Management. Jakarta : Edisi Sepuluh Salemba Empat. Lutnas, R.l, (2005). Oraganizational Behavioral. New York : McGraw-Hill.

Moleong, Lexy. (2007). Metodologi Penelitian Kualitatif. Bandung : PT Remaja Rosdakarya.

Marsono. (1996). Pemilihan Umum 1997 (Pedoman, Peraturan, dan Pelaksanaan). Yogyakarta : Djambatan.

Mangkunegara, Anwar Prabu, (2005). Evaluasi Kinerja SDM, Bandung, Refika Aditama.

Prawirosentono, S. (2004). Kebijakan Kinerja Karyawan. Yogyakarta : BPFE.

Prof. Dr. S. Nasution, M.A, (2004). Metode Research, Bumi Aksara, Jakarta.

Soehartono, Irawan. (2004). Metode Penelitian Sosial.PT.Remaja rosdakarya Bandung.

Sudijono, S. (1995).Pilaku Politik. Semarang : IKIP, Semarang Press

Sianipar, MM. (2000). Perencanaan Peningkatan Kinerja, LAN.

Simanjuntak, Payaman, (2005). Manajemen dan Evaluasi Kinerja, Jakarta :

LPFE UI. 
Ruky, Ahmad S, (2004). Sistem Manajemen Kinerja, Jakarta, PT. Gramedia Pustaka Utama.

Widodo. (2006). Kontrol Masyarakat Terhadap Kebijakan Publik, Gramedia Yogyakarta.

\section{Dokumen Pemerintah :}

Peraturan Presiden Nomor 80 Tahun 2018, Pasal 1 tentang Organisasi, tugas, Fungsi, Wewenang, dan Tata Kerja Bawaslu, Sekretariat Bawaslu Profinsi, Sekretariat Bawaslu Kabupaten/Kota dan Panwaslu Kecamatan.

Perbawaslu RI Nomor 14 Tahun 2017, tentang Penanganan Laporan Pelanggaran Gubernur dan Wakil Gubernur, Bupati dan Wakil Bupati, serta Wali Kota dan Wakil Wali Kota, Pasal 1.

Perbawaslu RI Nomor 12 Tahun 2018 Pasal 6, perubahan atas Perbawaslu Nomor 12 Tahun 2017, tentang pengawasan Kampanye peserta Pemilihan Gubernur dan Wakil Gubernur, Bupati dan Wakil Bupati serta Walikota dan Wakil Walikota.

Perbawaslu RI Nomor 20 Tahun 2018, tentang Pencegahan Pelanggaran dan Sengketa Pemilihan Umum.

Perbawaslu RI Nomor 7 Tahun 2018, tentang Penanganan Temuan dan Laporan Pelanggaran pemilihan umum.

PerbawasluRINomor 9 Tahun 2017, Tentang Pengawasan Pemutakhiran Data Dan Daftar Pemilih Dalam Pemilihan Gubernur Dan Wakil Gubernur, Bupati Dan Wakil Bupati Serta Walikota Dan Wakil Walikota.

Peraturan KPU Nomor 2 tahun 2017, tentang Pemutakhiran Data dan Penyusunan Daftar Pemilih dalam Pemilihan Gubernur dan Wakil Gubernur, Bupati dan Wakil Bupati dan/atau Walikota dan Wakil Walikota. 